\title{
Gêneros textuais e práticas de letramento: a temporalidade verbal no gênero crítica cinematográfica ${ }^{1}$
}

\author{
Text Genres and Literacy Practices: Verb \\ Tense and Time in the Movie Review Genre
}

Eliana Merlin Deganutti de Barros*

Universidade Estadual de Londrina

\begin{abstract}
RESUMO: Partindo do pressuposto de que o letramento é um processo de apropriação de gêneros de textos, apresentamos dados de uma pesquisa maior que se propóe a estudar a crítica de cinema como um gênero do jornalismo impresso que tem constituído, para o professor de língua portuguesa, um desafio para a sua transposição didática. Nosso objetivo é focalizar a temporalidade verbal, não como um simples conjunto de artefatos linguísticos regido por normas inflexíveis, mas como um mecanismo linguístico-discursivo que se processa no funcionamento efetivo do gênero. Nosso corpusé composto por dez críticas escritas por Carlos Eduardo Lourenço Jorge - publicadas na Folha de Londrina - e analisado a partir dos pressupostos do interacionismo sociodiscursivo, que toma a temporalidade verbal como um dos mecanismos de textualização responsável pela coerência temática do texto.
\end{abstract}

PALAVRAS-CHAVE: letramento; interacionismo sociodiscursivo; temporalidade verbal; gênero textual; crítica de cinema.

ABSTRACT: Based on the assumption that literacy is an appropriation process of textual genres, we present data from a larger research on film criticism as a genre of the press, which consists, for the Portuguese language teacher, in a challenge in terms of didactic transposition. The objective of this article is to approach verbal temporality, not as a simple set of linguistic devices controlled by inflexible norms, but as a linguistic-discursive mechanism that is processed in the effective functioning of the genre. The corpus consists of ten film criticisms written by Carlos Eduardo Lourenço Jorge - published in Folh a de Londrina - analyzed from the sociodiscursive interactionism perspective, which takes verbal temporality as one of the textual mechanisms responsible for textual thematic coherence.

KEYWORDS: literacy; socio-discursive interactionism; verbal temporality; textual genre; film criticism.

\footnotetext{
*edeganutti@hotmail.com

${ }^{1}$ Esse trabalho é um recorte da minha dissertação de mestrado defendida em maio de 2008 no Programa de pós-graduação em Estudos da Linguagem da UEL, intitulada "A apropriação do gênero crítica de cinema no processo de letramento", sob orientação da Profa. Dra. Elvira Lopes Nascimento.
} 


\section{Introdução}

Começamos nossa discussão com a seguinte pergunta: qual o objetivo maior do ensino da Língua Portuguesa nas escolas? É voz corrente há algum tempo que o ensino da língua materna é muito mais do que ensinar a sua gramática (no sentido tradicional da palavra), decorar normas que a regem, dominar uma vasta nomenclatura que só aos gramáticos interessa (cf. GERALDI, 2003). O processo de ensino e aprendizagem da língua deve "levar o aluno à construção gradativa de saberes sobre os textos que circulam socialmente" (BRASIL, 2006) (grifos nossos). Os primeiros Parâmetros Curriculares Nacionais - PCN (BRASIL, 1997), esquematizam os objetivos do ensino da língua materna por meio da tríade: aluno-língua-ensino:

O primeiro elemento dessa tríade, o aluno, é o sujeito da ação de aprender, aquele que age sobre o objeto de conhecimento. $\mathrm{O}$ segundo elemento, o objeto de conhecimento, é a Língua Portuguesa, tal como se fala e se escreve fora da escola, a língua que se fala em instâncias públicas e a que existe nos textos escritos que circulam socialmente. E o terceiro elemento da tríade, o ensino, é, neste enfoque teórico, concebido como a prática educacional que organiza a mediação entre sujeito e objeto do conhecimento (p. 25, grifos nossos).

Nessa citação dos PCN, podemos depreender três temas-chave: $\mathrm{o}$ aluno como sujeito do seu fazer, a língua em uso como objeto de conhecimento e a escola como mediadora do saber. Como vemos, mesmo esse texto tendo sido escrito há mais de dez anos, ele ainda reflete as necessidades atuais do ensino da língua. Vejamos, se o aluno tem de ser o sujeito da sua ação é porque ele não pode simplesmente ser um receptor passivo do conhecimento que a escola veicula. Transferindo essa visão para o contexto da língua Portuguesa, para esse sujeito ser um produtor de textos, autor de sua palavra, e um leitor (ou ouvinte) com atitude responsiva ativa (cf. BAKHTIN/VOLOCHINOV, 1986), ele precisa estar inserido em um processo formador que lhe dê possibilidade de se assumir como sujeito-aluno ${ }^{2}$ e possibilite-o vivenciar práticas de linguagem autênticas, socialmente disponibilizadas pelas instâncias sociais. Retomando os PCN, a escola precisa ser a mediadora entre as práticas sociais, estas perpassadas sempre pela linguagem, e o saber construído pelo aluno. Essa é uma postura de letramento escolar (KLEIMAN, 2006), tema tão discutido na atualidade.

${ }^{2}$ Falamos em "sujeito-aluno" e não simplesmente "sujeito", por entendermos que o ambiente escolar é sempre um ambiente didatizado. 
Para a pesquisa e o ensino de letramento, os variados usos da língua/ linguagem em situações socioculturais específicas requerem ferramentas teóricas e metodológicas que sejam sensíveis às diversas práticas sociais. A partir do momento que entendemos que toda prática social é perpassada por diversas práticas de linguagem, estas (re)configuradas em gêneros textuais (ver FIG. 1) - carta do leitor, convite para festa, sinopse de filme, receita culinária, romance, crítica de cinema -, a saber, forma padrão relativamente estável de estruturação do todo de um enunciado (BAKHTIN, 2003), podemos dizer que um indivíduo só é letrado em uma determinada prática de linguagem a partir do momento em que se apropria do gênero que a configura desenvolve capacidades para a leitura e/ou escrita desse gênero (ROJO, 2006; NASCIMENTO, 2007; PRETO-BAY, 2007; entre outros). Ora, sendo assim, qual o principal papel da Língua Portuguesa na escola? É, justamente, o de desenvolver nos alunos capacidades para se apropriarem dos diversos gêneros textuais que circulam socialmente.

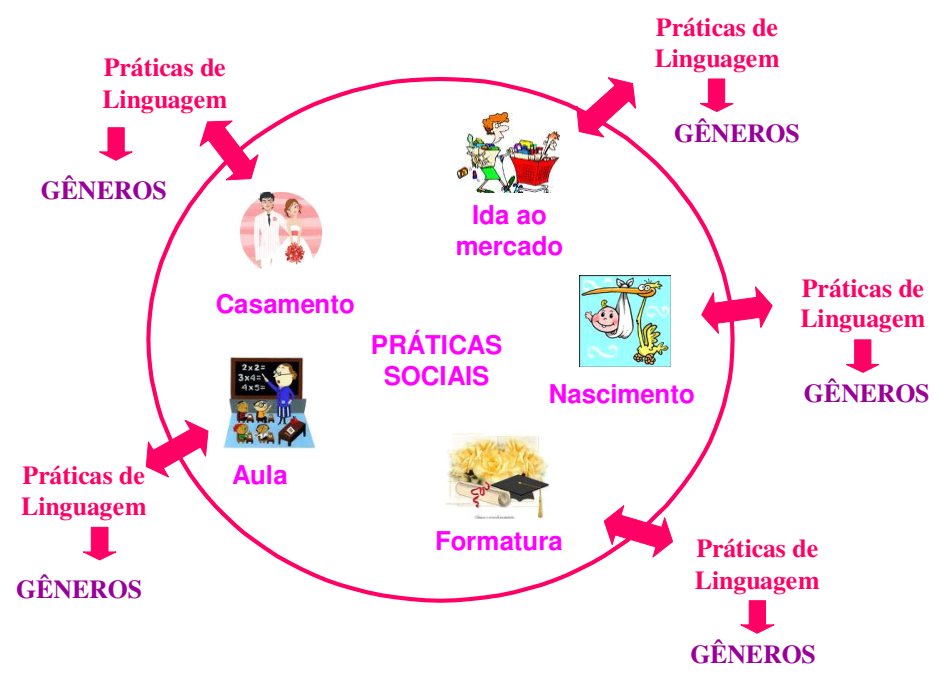

FIGURA 1: Relação entre práticas sociais, práticas de linguagem e gêneros ${ }^{3}$

Nos últimos anos, o enfoque nos gêneros textuais e seu uso situado tem se tornado o lugar central para o reconhecimento dos usos da linguagem nas

${ }^{3}$ Figura de nossa autoria. 
práticas sociais de uma sociedade, uma vez que são eles que sinalizam as diferenças da situação, da interação e do significado de tais atividades. $\mathrm{Na}$ interação letrada, indivíduos escrevendo e lendo um texto mediador têm de criar relações e significados compatíveis para estabelecer essa interação, o que pressupõe a noção de gêneros textuais como formas de ação social organizada.

Nessa perspectiva, entendemos que o gênero textual deve ser o instrumento mediador do processo de ensino/aprendizagem da língua. Assim como Rojo e Moita Lopes (2004), também nos posicionamos em favor de uma organização dos conhecimentos necessários ao uso e à compreensão da linguagem mediados pelos gêneros que não levem à separação as habilidades de leitura, produção e análise linguística. Essas habilidades estão todas intrinsecamente articuladas, pois para se elaborar um bom texto representativo de um gênero é preciso saber operar os elementos linguístico-discursivos que fazem parte do seu funcionamento. $\mathrm{O}$ mesmo acontece com a leitura: o desconhecimento funcional das particularidades linguístico-discursivas de um determinado gênero pode comprometer a compreensão textual. Ou seja, o desenvolvimento da capacidade de ação em relação a um gênero (capacidade de leitura e produção) está diretamente relacionado ao desenvolvimento de capacidades discursivas e linguístico-discursivas envolvidas nesse gênero.

Agora, como resgatar os conhecimentos que estabelecem o funcionamento dos diferentes gêneros existentes em nossa sociedade, a fim de que eles possam ser transpostos para a sala de aula? É pensando justamente nessa questão que o trabalho de investigação e descrição de um gênero se justifica como uma linha de pesquisa no campo da Linguística Aplicada. E é também essa a justificativa para a elaboração de um modelo analítico do gênero crítica de cinema, foco da nossa pesquisa maior (cf. BARROS, 2008), uma vez que não há como pensar nos gêneros como objetos de ensino sem que haja um trabalho primeiro de exploração/descrição desses objetos (ROJO, 2001). E, embora este trabalho não esteja diretamente atrelado à sala de aula, isto é, ao processo de ensino/ aprendizagem efetivamente realizado, o direcionamento do nosso olhar é sempre conduzido pelas necessidades do ensino institucionalizado da língua portuguesa na contemporaneidade.

Para compor esse artigo, objetivamos apresentar um recorte da nossa pesquisa de mestrado, enfocando o funcionamento da coesão verbal - categoria de análise do interacionismo sociodiscursivo - ISD - (BRONCKART, 2003, 2006, 2008; GUIMARÃES; MACHADO; COUTINHO, 2007) - em um gênero da esfera do jornalismo cultural: a crítica de cinema. $\mathrm{O}$ corpus da 
pesquisa é composto por dez críticas escritas por Carlos Eduardo Lourenço Jorge e publicadas no jornal Folha de Londrina. A partir dos pressupostos teóricos do ISD, a temporalidade verbal é analisada como um dos mecanismos de textualização responsável pela coerência temática do texto.

Cabe ressaltar que não pretendemos construir um modelo didático $o^{4} \mathrm{da}$ coesão verbal aplicada ao gênero crítica de cinema, da forma como é proposto pelos estudiosos de Genebra, já que não trabalhamos com um corpus diversificado (trabalhamos com críticas do mesmo autor/suporte) e também não nos direcionamos a um contexto escolar específico. Abordamos, sim, o funcionamento da temporalidade linguística, mediada pelo gênero crítica de cinema, sob a perspectiva das açôes de linguagem $^{5}$ de um agente-produtor situado sócio-historicamente em um contexto de produção. Acreditamos, pois, que o enfoque dado por nós à coesão verbal pode ser adaptado a diversos contextos textuais e de ensino/aprendizagem da língua.

Dessa forma, estabelecemos como objeto de investigação, não o gênero crítica de cinema na sua concepção mais genérica (embora seja esse o ponto de partida da pesquisa), mas, sim, açôes de linguagem resultantes de adaptações do gênero crítica de cinema feitas por um agente-produtor personificado na figura do crítico Lourenço Jorge. E, a partir do estabelecimento desse foco, delineamos como objetivo geral deste trabalho a investigação analíticodescritiva das ações linguageiras envolvidas no funcionamento da coesão verbal. Especificamente, temos por finalidade demonstrar a influência dos mecanismos da temporalidade verbal no estabelecimento da coerência temática dos textos que compóem o corpus, como também os efeitos de sentido que eles podem produzir no funcionamento textual, porém, sem deixar de lado as coerções exercidas pela situação de produção e pelo próprio gênero, na sua constituição como instrumento de interação social.

\footnotetext{
${ }^{4}$ Para um maior esclarecimento do conceito de modelo didático ver Schneuwly \& Dolz (2004, p. 180).

${ }^{5}$ Ação de linguagem é uma parte da atividade de linguagem (interpretação coletiva do agir pela palavra) cuja responsabilidade é atribuída a um indivíduo singular - o agente produtor dessa ação (BRONCKART, 2006, p. 139). Essa questão será discutida mais profundamente na fundamentação teórica da pesquisa.
} 


\section{Crítica de cinema: um gênero da esfera jornalística}

A crítica de cinema é um gênero mobilizado pela esfera jornalística (embora não seja exclusiva desta, já que também pode estar presente na discursividade do mundo acadêmico). É um gênero que transita entre o mundo jornalístico e o cultural, pois o tema que veicula pertence ao mundo das Artes, mas quem o veicula é a esfera jornalística. Ou seja, o crítico de cinema bebe em fontes culturais, nos primórdios da arte, porém, está coagido com os apelos imediatistas do mundo jornalístico. $\mathrm{O}$ gênero tem como suporte o jornal, a revista (tanto revistas de grande circulação, como revistas especializadas em cultura/cinema) e também a web (sites especializados em cinema/cultura e também versões on-line de jornais/revistas impressas).

Geralmente, a crítica de cinema aparece em seções ou cadernos especializados em entretenimento/cultura/arte/cinema, partilhando espaços com as outras modalidades de crítica, como a de livros ou CD. É comum a inserção de fotos de cenas do filme junto ao texto crítico.

O texto da crítica é sempre assinado, já que quem se responsabiliza pelo conteúdo veiculado é o próprio autor, e não o editor do jornal/revista. Esse crítico, quase sempre, é um jornalista, porém, nem sempre um especialista na área cinematográfica. Não há uma regularidade quanto à forma de enunciação, mas não são comuns textos escritos em primeira pessoa do singular. A crítica cinematográfica pode ter como objeto filmes prestes a estrear (como é o caso das críticas que analisamos), em cartaz, lançados em DVD ou que estão concorrendo em festivais cinematográficos.

A crítica de cinema é um gênero que tem como tema principal certa obra cinematográfica - alvo da crítica. O objetivo comunicativo do gênero transita entre a apresentação de informações do filme (data de estréia, gênero cinematográfico, duração, diretores, atores, etc.), a sumarização do enredo e a asserção valorativa de alguns aspectos da obra. A tendência, ora para a descrição das informações (aí compreendida a descrição factual da narração), ora para a argumentação crítica, vai depender do contexto em que a crítica está inserida: o tipo de suporte, o público-alvo, a linha editorial do jornal/revista, a competência e/ou o nível de especialização do crítico, os objetivos dos editores, etc. Em alguns casos, a crítica pode se assemelhar mais a uma "sinopse comentada".

$\mathrm{Na}$ atualidade, a crítica de cinema veiculada pelo jornalismo cultural, além das características prototípicas do gênero também passa a incorporar nuances do discurso jornalístico contemporâneo: ênfase na linguagem imagética (foto do filme-alvo em destaque, muitas vezes, ocupando espaço 
superior ao texto verbal), destaques aos títulos e subtítulos, inserção de informações fílmicas periféricas, extensão textual/verbal reduzida, etc.

\section{0 corpus da pesquisa}

O corpus desse estudo é composto por dez críticas de cinema - um dos gêneros presentes no caderno cultural da Folha de Londrina - escritas por Carlos Eduardo Lourenço Jorge ${ }^{6}$ e publicadas no período de 12/05/06 a $15 / 07 / 06$. Destas, cinco são direcionadas a filmes comerciais (circuito nacional - CN) e cinco a filmes exibidos em circuito alternativo (CA) na cidade. ${ }^{7} \mathrm{O}$ QUADRO 1 especifica os textos analisados:

QUADRO 1

Corpus da pesquisa

\begin{tabular}{|l|l|l|l|}
\hline Código & \multicolumn{1}{|c|}{ Filme } & \multicolumn{1}{|c|}{ Título da crítica } & Data da crítica \\
\hline 1-CA & Free Zone & As super-mulheres de “Free Zone” & $15 / 07 / 2006$ \\
2-CA & Clube da Lua & Receita argentina de cinema popular & $30 / 06 / 2006$ \\
3-CA & Dama de Honra & Quando a normalidade é aparente & $16 / 06 / 2006$ \\
4-CA & Sra. Henderson Apresenta & Entretenimento, como deve ser & $09 / 06 / 2006$ \\
5-CA & Conversando com Mamãe & Os planos de mamãe aos 80 & $12 / 05 / 2006$ \\
1-CN & Superman - O Retorno & SUPER-HOMEM - mais sério e & \\
& & menos pop & $14 / 07 / 2006$ \\
2-CN & Separados pelo Casamento & Estranha comédia romântica & $04 / 07 / 2006$ \\
3-CN & Carros & A animada lição de “Carros” & $30 / 06 / 2006$ \\
4-CN & A Profecia & Original mesmo só a data de estréia & $08 / 06 / 2006$ \\
5-CN & X-Men-O Confronto Final & Grandiloqüência MUTANTE & $26 / 05 / 2006$ \\
\hline
\end{tabular}

${ }^{6} \mathrm{O}$ crítico Lourenço Jorge tem formação acadêmica em Cinema e escreve para a Folha de Londrina desde 1971. Profissional de renome, comprometido com sua área de atuação e único crítico de cinema londrinense que escreve regularmente para um jornal da cidade.

${ }^{7}$ Filmes exibidos no Cine Com-Tour (projeto da Casa da Cultura/UEL) e que tem como programador o próprio crítico Lourenço Jorge. Dessa forma, os filmes referentes às críticas $\mathrm{CA}$ já foram alvo da avaliação do crítico em uma primeira instância, no momento da montagem da programação. 
As críticas CA referem-se a filmes mais eruditizados, próprios de um contexto "arte e ensaio" (a maioria oriundos de outras nacionalidades), destinados àqueles que apreciam um cinema "de qualidade". Já as críticas $\mathrm{CN}$ comportam filmes destinados à cultura de massa e exibidos nos grandes cinemas comerciais - são, na sua grande maioria, os chamados filmes hollywoodianos.

\section{ISD: pressupostos iniciais}

$\mathrm{Na}$ abordagem do interacionismo sociodiscursivo (ISD), a coesão verbal é um dos pilares da coerência temática ${ }^{8}$ de um texto - este sempre configurado em um gênero - contribuindo para a explicitação das "relações de continuidade, descontinuidade e/ou de oposição existentes entre os elementos de significação expressos pelos sintagmas verbais" (BRONCKART, 2003, p. 273). Ela inclui, de um lado, a abordagem da temporalidade, e de outro, o da aspectualidade. ${ }^{9}$ O que o ISD pretende com a sua proposta de análise não é esgotar essas duas categorias verbais, mas, sim, possibilitar que os mecanismos que as compõem possam ser analisados à luz de uma metodologia que sirva de base para a compreensão dos discursos humanos, já que a coesão verbal é uma peça fundamental na montagem do "quebra-cabeça" textual.

No modelo postulado pelo ISD para o exame da temporalidade verbal, as modalidades concretas de realização desses mecanismos dependem, fundamentalmente, dos tipos de discurso que atravessam. Essa particularidade no funcionamento da temporalidade implica, segundo Bronckart (2003, p. 313), "modos de localização próprios de cada tipo de discurso, que, por sua vez, são traduzidos por tempos verbais que, embora não sejam morfologicamente específicos (um tempo verbal e apenas um para um mesmo modo de localização), são, entretanto, portadores de valores específicos”. Dessa forma, antes de apresentarmos o modelo do ISD para a análise da temporalidade verbal, vejamos, brevemente, o que ele nos traz sobre os mundos discursivos e os tipos de discurso.

\footnotetext{
${ }^{8}$ Segundo Bronckart (2003), a coesão verbal, a coesão nominal e a conexão são os mecanismos responsáveis pela manutenção da coerência temática de um texto.

${ }^{9}$ Este trabalho enfoca apenas a questão da temporalidade, embora em alguns momentos possamos recorrer às noções de aspectualidade verbal.
} 


\subsection{Mundos discursivos e tipos de discurso}

Bronckart (2003) denomina mundo ordinário os mundos representados empiricamente pelos agentes humanos e, mundos discursivos, os mundos virtuais criados pela atividade de linguagem. A primeira bipartição que o autor faz é quanto às coordenadas gerais desses dois mundos. Temos então:

a) o mundo do NARRAR: quando as operações de construção das coordenadas gerais que organizam o conteúdo temático de um texto são apresentadas de maneira disjunta das coordenadas do mundo ordinário da ação de linguagem (exemplos: gênero fábula, parábola, conto);

b) o mundo do EXPOR: quando as representações mobilizadas não estão ancoradas em nenhuma origem espaço-temporal e organizam-se em referência direta às coordenadas gerais do mundo ordinário da ação de linguagem em curso - em conjunçáo com tais coordenadas (exemplos: gênero verbete de enciclopédia, dicionário, lista telefônica).

A segunda bipartição se refere aos parâmetros de agentividade. Um texto implica os parâmetros de ação de linguagem quando explicita as relaçôes que suas instâncias de agentividade mantêm com os parâmetros físicos da ação de linguagem (emissor, receptor, lugar físico, momento de produção), por meio de referências dêiticas. Por sua vez, quando um texto não explicita estas relações, dizemos que ele está em relação de autonomia com os parâmetros da ação de linguagem: suas instâncias de agentividade mantêm uma relação de interdependência ou indiferença com os parâmetros da ação comunicativa em curso. A partir do exposto, podemos distinguir quatro mundos discursivos: o mundo do NARRAR implicado, o mundo do NARRAR autônomo, o mundo do EXPOR implicado e o mundo do EXPOR autônomo:

QUADRO 2

Mundos discursivos

\begin{tabular}{|c|c|c|}
\hline $\begin{array}{l}\text { Coordenadas } \\
\text { Gerais dos } \\
\text { Mundos }\end{array}$ & $\begin{array}{l}\text { Disjunto (disante do mundo da interação } \\
\text { social em curso - Mundo de NARRAR } \\
\text { Conjunto dessa interação social em curso - } \\
\text { Mundo do EXPOR }\end{array}$ & $\begin{array}{l}\text { Mundos Discursivos } \\
\text { EXPOR implicado } \\
\text { EXPOR autônomo }\end{array}$ \\
\hline $\begin{array}{l}\text { Relação ao } \\
\text { Ato de } \\
\text { Produção }\end{array}$ & $\begin{array}{l}\text { - Implicado: presença explícita do lugar, } \\
\text { momento de produção, agente-produtor, } \\
\text { destinatário (não necessariamente todos). } \\
\text { * Autônomo: não apresenta essas marcas. }\end{array}$ & $\begin{array}{l}\text { NARRAR implicado } \\
\text { NARRAR autônomo }\end{array}$ \\
\hline
\end{tabular}


Para cada um desses mundos criados virtualmente pela ação de linguagem, temos um tipo de discurso correspondente, ou seja, um "tipo de discurso tal como ele é semiotizado no quadro de uma língua natural, com suas propriedades morfossintáticas e semânticas particulares" (BRONCKART, 2003, p. 156). Vejamos os quatro tipos de discursos resultantes da semiotização dos mundos discursivos:

a) O mundo do NARRAR implicado: relato interativo;

b) O mundo do NARRAR autônomo: narração;

c) O mundo do EXPOR implicado: discurso interativo;

d) O mundo do EXPOR autônomo: discurso teórico.

\subsubsection{Análise: os tipos de discurso no funcionamento da crítica de cinema}

Levando em consideração as operações psicológicas que norteiam a textualidade como um todo, ou seja, a intenção primeira que sustenta, que dá suporte à discursividade da crítica de cinema, verificamos que, ao mobilizar representaçôes e criar um mundo discursivo, o agente-produtor intenciona expor, comentar sobre um determinado conteúdo temático (filmes que entrarão em cartaz na semana) que está conjunto ou se refere diretamente ao mundo empírico da ação de linguagem.

Quanto à implicação ou à autonomia desse EXPOR, observamos que as marcas linguísticas analisadas não delimitam claramente um tipo de discurso. Ora apresentam características do discurso interativo (EXPOR implicado), ora do discurso teórico (EXPOR autônomo). Assim, podemos dizer que a discursividade se encontra em processo de fusionamento, formando o que Bronckart (2003, p. 192) denomina de discurso misto interativo-teórico (principal ou dominante). Tanto há a apresentação de informações que são, aos olhos do enunciador, verdades autônomas, independentes das circunstâncias do contexto físico de produção da ação de linguagem, como o enunciador, mesmo na ausência de um contato direto com o destinatário, solicita sua atenção, procura sua aprovaçãa, seu envolvimento, antecipando suas objeções, inscrevendo-se, assim, nas coordenadas de um mundo interativo. ${ }^{10}$

${ }^{10}$ Essa dualidade discursiva pode ser vista, primeiramente, pelas especificidades do gênero crítica de cinema: um gênero que ao mesmo tempo em que necessita trazer à tona um conhecimento teórico/factual em relação a um determinado filme, também 
Entretanto, na constituição do "emaranhado" textual, entrecruzam outros tipos de discursos, porém de caráter secundário. Nas críticas analisadas, destacamos a mobilização discursiva do enredo ficcional do filme criticado (intertextualidade explícita com o roteiro fílmico). Essa mobilização é feita por meio de segmentos discursivos de narração, encaixados no discurso dominante (discurso misto interativo-teórico) e não planificados na forma convencional de uma sequência narrativa ${ }^{11}$ já que se narra uma mínima parte da trama (e nunca seu final) e somente aquelas que mais interressam à orientação argumentativa em curso. Ressaltamos que não há uma divisão clara, nítida entre a textualidade de elementos temáticos referentes ao filme como história ficcional e ao filme como produto de consumo e/ou fruição. Essa atividade narrativa também não se encontra delimitada por marcadores discursivos convencionais e, muitas vezes, aparece imbricada com a exposição em curso.

A narração ficcional do enredo não é a única ocorrência discursiva do plano secundário. Entretanto, nosso objetivo aqui não é fazer uma exploração exaustiva da discursividade da crítica de cinema, apenas levantar os pontos mais significativos, aqueles que caracterizam o gênero. Sendo assim, nos limitamos a abordar a narração ficcional do enredo, uma vez que esta perpassa a identidade do gênero analisado.

\subsection{A temporalidade expressa pelos verbos}

A relação tempo e verbo se encontra, nas gramáticas tradicionais, compartimentada de forma estanque, nos já conhecidos "paradigmas verbais": presente, passado e futuro, com suas clássicas subdivisões: pretérito perfeito, imperfeito, mais-que-perfeito, futuro do presente, do pretérito, etc. Essas divisões, "incontestáveis no seu princípio, estão, no entanto, longe das realidades de

se propõe a traçar uma linha argumentativa de convencimento a respeito de um ponto de vista assumido pelo crítico, o que requer, sem dúvida, formas discursivas interativas, de aproximação com o leitor. Em segundo lugar, como pudemos analisar por meio da entrevista concedida pelo crítico Lourenço Jorge (cf. BARROS, 2008), ele se encontra em um momento de transição discursiva, em um embate entre uma forma mais tradicional, mais formal de escrita (que ora ele considera própria do gênero, ora atribui a sua formação intelectual mais formal) e uma busca de interatividade com seu público.

${ }^{11}$ A forma prototípica de uma seqüência narrativa inclui as seguintes fases: situação inicial, complicação, ações, resolução, situação final; podendo ainda ter: as fases da avaliação e a da moral (BRONCKART, 2003, p. 219-222). 
emprego e não são suficientes para seu agrupamento" (BENVENISTE, 1992, p. 29). Com certeza, o desvendamento da noção de tempo e seu funcionamento na linguagem humana é algo muito mais complexo. Sendo assim, estaremos muito afastados de uma compreensão temporal adequada se somente nos determos nos paradigmas que as gramáticas tradicionais nos trazem, sem, contudo, pensarmos em uma metodologia mais abrangente e mais flexível que possa dar conta das noções semânticas da temporalidade verbal, pelo menos, as mais importantes.

Bronckart (2003) critica a abordagem padrão da temporalidade, por esta ser, ao mesmo tempo, binária e fisicalista. Binária em razão das relações temporais serem estabelecidas somente entre dois termos, a saber, momento da produção e momento do processo estabelecido pelo verbo; e fisicalista, por esses momentos serem definidos de forma objetiva. Foi Reichenbach (1947/1966) o primeiro lógico a formalizar uma interpretação temporal das línguas naturais, estabelecendo três pontos teóricos na linha do tempo: ao momento da produção e ao momento do processo, ele acrescenta o momento psicológico de referência (cf. CORÔA, 2005, p. 20; BRONCKART, 2003, p. 276). Cria-se, assim, uma concepção tricotômica da temporalidade. E é a partir dessa nova concepção que Bronckart (2003) elabora o seu quadro teórico-metodológico para a análise dos mecanismos da coesão verbal. As três categorias dos parâmetros temporais são reformuladas, eliminando o termo "momento" que, segundo o autor, é incompatível dentro da abordagem da temporalidade (cf. BRONCKART, 2003, p. 281-282), incluindo a noção de tipos de discurso e integrando algumas dimensões gerais das funções aspectuais. A tricotomia fica assim descrita:

1. Os processos ${ }^{12}$ efetivamente verbalizados, com suas diversas propriedades aspectuais e sua propriedade eventual de situabilidade temporal objetiva;

2. Os eixos de referência, eixo global associado a um tipo de discurso;

3. A duração psicológica associada ao ato de produção.

Com base nos parâmetros abordados, o autor elabora quatro funções para a coesão verbal: temporalidade primária, temporalidade secundária, contraste global e contraste local; que possibilitam uma análise particular do funcionamento da temporalidade verbal. O quadro de análise, na perspectiva do ISD, fica assim elaborado:

\footnotetext{
12 "Processo designa o significado correspondente ao significante que constitui o lexema verbal” (BRONCKART, 2003, p. 278).
} 
QUADRO 3

As quatro funções da coesão verbal

\begin{tabular}{|l|l|}
\hline $\begin{array}{l}\text { Temporalidade } \\
\text { primária }\end{array}$ & $\begin{array}{l}\text { Essa função estabelece um modo determinado de localização do } \\
\text { processo em relação a um dos parâmetros de controle (eixos de referência } \\
\text { ou duração associada ao ato de produção): } \\
\text { - Localizaçâes de anterioridade (L. ant.), posterioridade (L. post.) } \\
\text { e simultaneidade (L. sim.): o parâmetro é a duração associada ao ato } \\
\text { de produção; } \\
\text { - Localizaçóes neutras (L. neutras), isocrônicas (L. iso.), retroativas } \\
\text { (L. retro.) e projetivas (L. proj.): o parâmetro é o eixo de referência } \\
\text { global de um tipo de discurso. }\end{array}$ \\
\hline $\begin{array}{l}\text { Temporalidade } \\
\text { secundária }\end{array}$ & $\begin{array}{l}\text { Consiste em situar um processo em relação a um outro (que por sua vez } \\
\text { é objeto de uma localização na temporalidade primária): } \\
\text { - Função de anterioridade relativa (L. ant. r.), simultaneidade relativa } \\
\text { (L. sim. r.) e posterioridade relativa (L. sim. r.). }\end{array}$ \\
\hline Contraste global & $\begin{array}{l}\text { Séries isotópicas de processos são distinguidas: uma fica em primeiro } \\
\text { plano e as outras em segundo plano. }\end{array}$ \\
\hline Contraste local & $\begin{array}{l}\text { Consiste em apresentar um processo como um quadro sobre o qual se } \\
\text { destaca, localmente, outro processo. }\end{array}$ \\
\hline
\end{tabular}

As funções de temporalidade (primária e secundária) consistem em relacionar um dos parâmetros de controle ao processo em curso ou situar esse processo em relação a um determinado parâmetro; já a função de contraste consiste não em relacionar, mas em opor os processos entre si (cf. BRONCKART, 2003, p. 283-308).

\subsubsection{Análise: a temporalidade verbal no funcionamento da crítica de cinema}

A nossa análise parte da articulação entre o funcionamento da coesão verbal e os tipos de discurso analisados no corpus da pesquisa. Por razões didáticas, as análises serão processadas a partir de "recortes" textuais previamente selecionados, o que não indica que nossa posição seja de um ensino fragmentário da língua enquanto prática social. Estamos, tão somente, nos adaptando a uma dada situação acadêmica.

Como já foi exposto anteriormente, identificamos, em nossas críticas, um tipo de discurso dominante misto teórico-interativo, que tem como uma de suas características a não delimitação clara entre um EXPOR que implica os parâmetros da situação de produção e um EXPOR autônomo em relação 
a esses parâmetros. Os fragmentos (1) e (2) exemplificam a coesão verbal nesse tipo de funcionamento discursivo. Primeiramente, vejamos o exemplo (1): $:^{13}$

(1) Eles da Pixar, à frente o mentor John Lasseter das 'Toy Story', sabem (L. neutra) que a harmonia somente ocorre (L. neutra) através da narrativa e não somente pelo número de efeitos e risos que provocam (L. neutra). A lição aparece (L. neutra) clara, límpida, neste 'Carros' que chega (L. sim.) hoje em lançamento nacional (veja (L. sim.) a programação de cinema na página 2). (3-CN).

No trecho (1), referente à crítica ao filme "Carros", temos uma passagem na qual o expositor ${ }^{14}$ coloca seu ponto de vista em relação ao filme em questão. O mundo discursivo aí criado é o do expor. Mas o eixo de referência temporal ora é o do próprio processo expositivo ora é a duração associada ao ato de produção. No primeiro caso, os elementos conteudísticos são apresentados como se "sua validade fosse absoluta ou pelo menos como se sua validade fosse independente das circunstâncias particulares do ato de produção" (BRONCKART, 2003, p. 301) - características próprias do discurso teórico. Os processos expressos por sabem, ocorre, provocam, aparece são apresentados como necessariamente incluídos em uma temporalidade ilimitada (ou atemporalidade de referência), sendo, assim, objetos de uma localização neutra, e expressos por um presente com valor genérico ou gnômico (cf. BRONCKART, 2003, p. 308). Segundo Fiorin (1999, p. 151), tal forma de presente é utilizada não só para enunciar as verdades absolutas, mas também aquelas que se pretendem como tais. É o que justamente vemos no fragmento (1) quando o crítico coloca: os mentores da Pixar sabem obter a harmonia narrativa em um filme de animação computadorizada, e em "Carros" essa lição aparece límpida. Ou seja, não é que essas sejam verdades incontestáveis, mas há uma intenção discursiva que as coloca nessa posição.

Ainda no exemplo (1), como mencionamos anteriomente, temos outro eixo de referência temporal - a duração associada ao ato de produção - próprio do discurso interativo (este tipo de discurso, por definição, implica os parâmetros da situação, ou, pelo menos, alguns deles). Entretanto, a relação

${ }^{13}$ Todos os grifos (negrito e sublinhado) dos exemplos foram feitos por nós. As siglas que aparecem junto aos verbos são descritas no quadro 3 .

14 "O narrador e o expositor são as instâncias teóricas às quais o agente produtor atribui a 'responsabilidade do dizer' e sob a égide dos quais se desenvolvem, respectivamente, o processo narrativo e o expositivo" (BRONCKART, 2003, p. 281). 
entre os processos chega e veja e o ato de produção "não apresenta o caráter fisicalista que lhe atribuem as teorias-padrão. O que é colocado em relação com o processo não é o 'momento' físico de produção, mas, sim, uma duração representada, construída em torno (ou a partir) do ato de produção" (BRONCKART, 2003, p. 304). Ou seja, não há como definir objetivamente o "momento" preciso da produção. Nesse exemplo, o ponto de referência que temos é a data da publicação da crítica, que embora seja um elemento extratextual, é o parâmetro pelo qual nos orientamos. Agora, saber exatamente o instante do ato de produção é absolutamente impossível e, certamente, desnecessário. No exemplo em foco, os processos marcados pelo tempo verbal presente-chega e veja-são apresentados como inclusos nos limites da duração associada ao ato de produção (no caso, o parâmetro é 30/06/06), marcando uma localização de simultaneidade em relação a esse eixo.

Agora, o que distingue o tempo verbal presente da localização neutra e o presente da localização simultânea no exemplo (1)? Como sabemos que o processo expresso por um está ancorado no eixo discursivo e, o outro, no eixo marcado pelo ato de produção? Segundo Bronckart (2003), não há como apreender o valor que os verbos e seus determinantes assumem em seu quadro funcional efetivo se não levarmos em consideração o quadro geral da organização dos textos e dos discursos que os veicula. Na textualidade proposta pelo trecho (1), percebemos que um dos fatos que marca a implicação discursiva, e, consequentemente, a marcação de um eixo de referência ao ato de produção, é a mobilização do adjunto adverbial hoje. Benveniste (1995) distingue dois tipos de adjuntos: um ancorado na enunciação (os dêiticos), e outro no co-texto (não-dêiticos). O hoje do trecho (1) seria um exemplo de dêitico com valor de simultaneidade ao ato de produção, ou seja, quando o crítico diz que o filme chega hoje aos cinemas, sabemos que esse hoje, por ter um valor dêitico, se refere ao dia da publicação da crítica (nosso ponto de referência com o ato de produção). É a mobilização de tal adjunto que nos possibilita diferenciar o presente expresso em chega e o presente de ocorre, por exemplo, e determinar um tipo de localização temporal distinta para cada um.

No caso de Veja... na página 2, o processo é um pouco diferente. Primeiramente, temos um verbo no modo imperativo, assim, "fala-se diretamente a um interlocutor" (RYAN, 1996, p. 19). No exemplo em particular, para expressar uma recomendação, uma sugestão, isto é, caso o leitor se interesse pelo filme, ele pode verificar a programação. Como vemos, o elemento dêitico implicado é o outro, aquele a quem o discurso é dirigido, a 
saber, os leitores da Folha de Londrina. Entretanto, não há como nos dirigir a alguém sem também sermos implicados nesse processo. Segundo Benveniste (1992), a segunda pessoa do discurso é uma forma que presume ou suscita uma pessoa fictícia e institui, por isso, uma relação vivida entre o eu e essa "quase-pessoa" (o tu). Dessa forma, ao usar o imperativo, é como se a primeira pessoa do singular tivesse sido automaticamente mobilizada.

$\mathrm{Na}$ passagem em questão, diferentemente da anterior, é o próprio processo que determina o eixo de referência e não o adjunto, pois o valor dêitico está expresso pelo verbo e é esse que possibilita inferirmos a página 2 não como uma numeração textual da própria crítica, mas, sim, do caderno cultural: (veja - o quê? - a programação - onde? - na página 2 do caderno cultural). Esse adjunto adverbial de lugar não é um dêitico na sua forma convencional, ou seja, o espaço que ele indica não é o do ato de produção em si. Ele é um "apontador" extra-textual que nos remete para o suporte do gênero. O interessante é que o crítico parte do pressuposto de que seu leitor tem conhecimento desse fato. Um ponto a se ressaltar nessa estratégia discursiva é a apresentação do conteúdo entre parênteses. Esse recurso textual parece servir para aproximar autor e leitor: é como se, no interior dos parênteses, o crítico pudesse se direcionar mais abertamente ao seu público, por isso, o uso do imperativo.

Vejamos, agora, o exemplo (2):

(2) Entre sua filmografia [do diretor], elejo (L. sim.) quatro títulos capitais: "As Corças" (67), "O Açougueiro" (69), "Madame Bovary" (91) e "Mulheres Diabólicas" (95). Em comum, um método narrativo que não se apóia (L. neutra) na trama geralmente freqüentada por crimes -, mas a utiliza (L. neutra) como pretexto; menos ênfase no suspense e total entrega ao desenho dos personagens, à sua psicologia, à sua vida interior e ao retrato do entorno familiar e social. "A Dama de Honra" não é exceção. (3-CA).

No fragmento (2), da mesma forma que no anterior, temos uma dupla ancoragem temporal: em elejo, o eixo de referência é o ato de produção, constituindo uma localização de simultaneidade em relação a ele, marcada pelo tempo verbal presente. Em apóia e utiliza, o eixo é o estabelecido pelo tipo de discurso, no caso, uma atemporalidade marcada pelo presente genérico, constituindo, assim, um tipo de localização temporal neutra. A diferença é que, no exemplo em questão, a localização de simultaneidade é estabelecida pela implicação da instância enunciativa, isto é, sabemos que quem elege, dentre 
a filmografia do diretor de "A Dama de Honra", quatro filmes como principais é o expositor encarnado na pessoa do crítico Lourenço Jorge. "Eu só utilizo um eu ao dirigir-me a alguém, que na minha alocução será um $t u$ " (BENVENISTE, 1992, p. 51). Dessa forma, ao implicar o sujeito do discurso, consequentemente, implica-se o outro (o tu) e também o eixo de referência temporal - o ato de produção.

Nos fragmentos (3) e (4), a ênfase é na mobilização do conteúdo temático referente à história ficcional do filme. Como podemos observar, não há uma delimitação clara que separa o discurso expositivo (filme tomado como produto comercial, de fruição - plano conjunto ao mundo ordinário da ação de linguagem) e o discurso narrativo (abordagem do enredo ficcional da trama/roteiro - plano disjunto ao mundo ordinário da ação de linguagem). Comecemos pela crítica 1-CA referente ao filme "Free Zone":

(3) Três mulheres muito diferentes entre si protagonizam (L. neutra)"Free Zone". A mais jovem é (L. iso.) norte-americana. Outra, de caráter mais forte, é (L. iso.) israelense. A terceira, sensível e misteriosa, é (L. iso.) palestina. As três unem (L. iso.) seus destinos naquela citada zona de comércio. Ao longo da narrativa, o espectador vai conhecendo as reais motivações de cada uma dela.

Rebecca (Natalie Portman, atriz de origem israelense), filha de pai judeu e mãe não judia, acaba de romper com o noivo Julio (Aki Avni), israelense de origem espanhola. Discute (L. iso.) com ele, sai correndo e entra (L. iso.) num táxi, conduzido pela autoritária, resoluta e sincera Hanna (Hanna Laszlo, melhor atriz ano passado em Cannes). Tornam-se amigas. E decidem (L. iso.) fazer uma viagem até a fronteira.. (1-CA).

No trecho (3), podemos observar como não é fácil a delimitação entre o discurso da ordem do expor e o discurso referente à atividade narrativa ficcional, já que ambos têm o tempo verbal presente como marco temporal e estão, muitas vezes, interligados um ao outro. A primeira frase mobiliza o lexema verbal protagonizam, que por sua natureza semântica ambígua, nos permite uma dupla interpretação: ou protagonizam se refere às personagens da ficção ou às próprias atrizes que as representam. É o desenrolar do discurso que nos permite compreender que as mulheres que protagonizam "Free Zone" fazem parte, na verdade, da ficção fílmica. Entretanto, esse protagonizar não tem como referência o eixo temporal do discurso do narrar, ele ainda faz parte da discursividade expositiva, pois personagens são, estão, agem dentro de uma 
narrativa, eles não protagonizam um filme. Dessa forma, essa primeira frase, mesmo introduzindo um conteúdo da narração ficcional, ainda faz parte do discurso dominante do expor, e o processo verbal que mobiliza (protagonizam) marca, assim, um tipo de localização temporal neutra.

Observamos que os três processos seguintes são expressos pelo verbo de estado é(verbo ser), e fazem parte do desenvolvimento de fases da aspectualização de uma sequência descritiva (cf. BRONCKART, 2003, p. 222-225) introduzida pelo tema-título "Três mulheres muito diferentes entre si", que se encontra na primeira frase analisada - mulheres estas consideradas por nós como personagens e não atrizes. Sendo assim, podemos incluir essas descrições como parte de um discurso narrativo que começa a se desenvolver, e que tem o presente como tempo básico. Na narração, o eixo de referência temporal pode ser definido como a duração formal do processo narrativo que se desenvolve a partir de uma origem absoluta, responsável por estabelecer uma relação de indiferença à duração do ato de produção (cf. BRONCKART, 2003, p. 285). Os processos representados no fragmento (3), por meio das três recorrências da forma verbal $e$, estão, dessa forma, ancorados no eixo temporal narrativo, registrando, assim, um tipo de localização temporal isocrônica em relação a este eixo. Segundo Bronckart (2003, p. 296), quando as narraçóes têm o presente histórico (presente utilizado nas narraçōes) como tempo básico, este "marca uma nítida ênfase da localização isocrônica dos processos em relação ao eixo de referência temporal, [...] o curso do processo narrativo coincide estritamente com a progressão da diegese, o que interdita, praticamente, qualquer estabelecimento de contraste global”. Dessa forma, não há uma oposição primeiro/segundo plano, marcada, normalmente, pela oposição pretérito perfeito/pretérito imperfeito, nas atividades narrativas que têm como tempo-base o pretérito. Ou seja, nesse exemplo, temos um único plano narrativo.

$\mathrm{Na}$ frase seguinte: "As três unem seus destinos naquela citada zona de comércio", a isocronia representada pelo tempo presente colabora para a mescla entre discurso da ordem do expor e do narrar, já que a ação em curso é representativa da atividade narrativa, mas o adjunto adverbial de lugar naquela citada remete a um segmento expositivo citado no início do texto. Esse é um caso típico da imbricação entre os dois mundos discursivos, o que gera, com certeza, uma grande complexidade textual. Além da narração do enredo ter o presente como âncora temporal, ela também é bem atípica, no sentido de que não apresenta uma origem espaço-temporal explícita da qual os fatos se sucederiam, como também, quase sempre, não mobiliza conectores temporais 
para o estabelecimento dessa sucessão. Dessa forma, é justamente o discurso teórico-interativo (dominante) que auxilia a interpretação da atividade narrativa, como podemos perceber na próxima frase do nosso exemplo: "Ao longo da narrativa, o espectador vai conhecendo as reais motivaçóes de cada uma delas"; na qual o expositor, instância exterior ao mundo da narração, mobiliza conteúdos desse mundo narrativo, mas sem assumir o papel de narrador (o que há, na realidade, é um tipo de "exposição da história narrada").

O tempo de base nos segmentos narrativos do segundo parágrafo do trecho (3) continua sendo o presente histórico - marcado por uma localização temporal isocrônica em relação ao eixo de referência da narração em curso. Nessa passagem é possível visualizar a manobra textual/discursiva para que o processo narrativo tenha êxito. O primeiro processo mobilizado é expresso pela perífrase verbal acaba de romper que, ao lado do aspecto verbal de acabado, expressa também uma noção temporal de passado recente (cf. TRAVAGLIA, 1981, p. 238). Dessa forma, mesmo o tempo verbal do auxiliar estando no presente, é o efeito de sentido de um passado recente que estipula um marco temporal, a partir do qual conseguimos nos situar em relação aos outros acontecimentos que são narrados (sempre posteriores).

O primeiro encadeamento desses acontecimentos (discute... sai correndo e entra) consegue um efeito de sucessão temporal muito nítido, sem, contudo, abandonar o tempo presente e sem buscar auxílio de marcadores temporais. Isso se deve pelo valor que cada processo assume na narrativa. Discute tem um valor aspectual de acabamento (não-durativo), por isso, sabemos que o próximo evento não se encontra em simultaneidade a ele. Em sai correndo temos um gerúndio sendo usado ao lado de um verbo de acabamento como se fosse um adjunto adverbial de modo "para indicar uma ação simultânea" (RYAN, 1996, p. 24), porém, a aproximação a um gerúndio (processo verbal em ação) anula o valor de acabamento de saio e o efeito passa a ser de uma ação durativa, de um "prolongamento" do ato de sair/correr, que só é quebrado com a adição de um verbo de acabamento: e entra. Já, a sucessão dos demais acontecimentos é marcada textualmente pela acomodação de cada processo em uma única frase sintática.

Vejamos agora outro exemplo:

(4) Mas o grande momento do filme corre por conta da reaparição de Mia Farrow como a insólita baby-sitter de Damien. Surpreendentemente jovem e bonita - botox na medida certa -, Mia Farrow se apresenta (L. iso.) ao casal com o currículo e revela (L. iso.): "Há (L. sim.) quase 40 anos venho criando (L. sim.) meninos", ela diz (L. iso.) com sorriso angelical. (4-CN). 
O trecho grifado no exemplo (4) ilustra um encaixamento de uma passagem da ordem do narrar no discurso expositivo dominante, e o segmento entre aspas (marcação do texto original), um encaixamento de um discurso interativo nessa narração (aqui, o mundo criado é o do discurso interativo relatado-BRONCKART, 2003, p. 159). Vejamos como se processa a coesão verbal nesse caso. O discurso narrativo, como nos exemplos anteriores, tem como tempo-base o presente histórico, sendo os processos apresentados a partir de localizações isocrônicas (se apresenta, revela, diz). Entretanto, ao criar outro mundo discursivo, a saber, o do discurso interativo relatado, o eixo de referência passa a ser marcado em relação a esse novo parâmetro. Assim, o tempo verbal presente do segmento interativo em pauta não se encontra em isocronia em relação ao eixo do discurso narrativo, está, sim, em localização de simultaneidade em relação ao mundo ficcional do personagem que é colocado em cena por meio do discurso direto. Isto é, esse presente não é o mesmo do discurso narrativo que o introduziu, nem tão pouco o do discurso expositivo dominante. É justamente essa diferenciação que o leitor atento nunca pode perder de vista, pois sem ela, a coerência temática do texto fica totalmente comprometida. Interessante também, nessa passagem, é a intersecção entre a figura de Mia Farrow como atriz (elemento da exposição dos fatos) e como personagem fictício da narração: "Mia Farrow se apresenta ao casal com o currículo e revela"; na verdade, não é Mia Farrow quem se apresenta, mas a personagem, a baby-sitter da trama.

Por último, vamos analisar uma passagem de um relato interativo encaixado no início do discurso expositivo dominante como forma de contextualização de parte do conteúdo temático de "A Dama de Honra" e como âncora argumentativa:

(5) Em conversa com o crítico francês Michel Rebichon, da revista Studio, à saída da sessão para a imprensa de "A Dama de Honra", no Festival de Veneza de 2004, ouvi (L. iso.) dele que o diretor Claude Chabrol faz sempre o mesmo filme. Perguntei (L. iso.) se a observação era (L. iso.) uma crítica, espécie de acerto de contas doméstico. Ele então argumentou (L. iso.) que o propósito de Chabrol era (L. iso.) cada vez mais depurar o olhar para alcançar a máxima precisão no traço, a maior concisão na construção de suas histórias e a mais maliciosa e fina sutileza para obter incômoda e provocadora ambigüidade. Nada mais pertinente. O filme, um fascinante convite à reflexão acerca do mal que se esconde sob a aparência mais corriqueira e cotidiana, estréia hoje na cidade (veja a programação de cinema na página 2). (3-CA). 
No relato interativo, como na narração, o eixo de referência temporal é constituído pela duração formal do processo narrativo que se desenvolve a partir de uma origem espaço-temporal, e não pelo eixo da duração associada ao ato de produção. A diferença é que no relato essa origem é dêitica: ela pode ser calculada em relação ao ato de produção. $\mathrm{O}$ marco estabelecido em (5) exemplifica bem esse fato: no Festival de Veneza de 2004 - colocado em relação ao ato de produção, que no nosso caso pode ser estipulado pela data da crítica (junho de 2006), estabelece um vácuo temporal de aproximadamente dois anos (claro que, para o leitor que saiba o mês do Festival, essa conta se torna mais exata).

Diferentemente do presente histórico utilizado para narrar o enredo fílmico, nessa passagem de relato interativo, como podemos observar, o tempobase é o pretérito. E é ele que marca a isocrônia em relação ao marco temporal inicial da narrativa. Tanto o pretérito perfeito como o imperfeito do indicativo marcam, nesse tipo de discurso, essa localização temporal isocrônica. Eles só se opõem quanto à função de contraste global: os processos expressos pelo pretérito perfeito são colocados em um primeiro plano, enquanto os expressos pelo imperfeito estão num segundo plano do discurso. É a oposição observada entre pergunteilera e argumentoulera. Nota-se que o primeiro plano refere-se aos verbos introdutórios do discurso indireto e, o segundo plano, aos verbos reportados.

Essa distinção só não existe no par ouvilfaz, já que, em vez do imperfeito utiliza-se o presente simples. Agora, como explicar o uso do presente em um relato que tem como marco temporal o passado, ou seja, para esse tipo de discurso, o presente não existe, ou não deveria existir. Na verdade, o efeito de sentido que se obtém em "ouvi dele que o diretor Claude Chabrol faz sempre o mesmo filme" é de uma transposição para o discurso interativo da ação de linguagem, uma quebra de barreiras entre os mundos discursivos estabelecido durante a textualidade. O propósito de mobilizar este faz talvez seja a intenção do crítico de estender essa ação até a atualidade do ato de produção - o diretor não só fazia o mesmo filme (até a data de 2004), mas ele ainda faz (até a data da crítica). Talvez essa estratégia argumentativa tenha sido usada para mostrar uma concordância de opinião em relação ao crítico francês, uma vez que o presente é o tempo mobilizado tanto para a exposição, comentário ou avaliação crítica do filme.

\section{Discussões finais}

Após analisarmos o funcionamento da coesão verbal nas críticas cinematográficas que constituem nosso corpus de pesquisa, pudemos perceber com mais nitidez como, realmente, a coerência temática depende de uma clara 
interpretação de seus mecanismos de controle. No caso específico de nossas críticas, parece-nos evidente o grau de complexidade textual que as envolve, principalmente, no que diz respeito ao diálogo entre o mundo expositivo e o narrativo na elaboração da textualidade e na determinação da temporalidade verbal, fato que constitui, sem dúvida, um desafio para a transposição didática desse gênero textual.

O leitor (professor, aluno) precisa ficar atento para distinguir as várias representações da temporalidade, sobretudo, os vários valores que o tempo verbal presente toma em cada funcionamento discursivo: a) presente genérico, no discurso expositivo com eixo de referência atemporal; b) presente com valor dêitico, próprio dos discursos interativos; c) presente marcado pela simultaneidade entre o processo verbal e o mundo do discurso interativo relatado criado pelo narrador; d) presente histórico, mobilizado nas várias passagens de narração do enredo ficcional do filme.

Além da distinção dos vários presentes da crítica, um fato de extrema complexidade na análise da coesão verbal desse gênero é a articulação entre o discurso expositivo dominante e a narração ficcional do enredo, articulação esta ancorada na temporalidade de cada tipo de discurso. A complexidade reside no fato de tanto o mundo do EXPOR como o mundo do NARRAR ter o presente como eixo temporal. O uso do presente histórico para narrar a trama fílmica cria um efeito de sentido de aproximação com a realidade, ou seja, parece que o que se está narrando não é uma ficção e, sim, algo do mundo "real", algo da instância do "aqui" e "agora". O que se pretende enfatizar não é a história ficcional, mas o filme em si como um produto cultural que está disponível para ser consumido no momento presente da enunciação. Não podemos esquecer que um dos objetivos da crítica é justamente a divulgação (comercial?) de uma produção fílmica.

Já, a relevância do trabalho em pauta se deve ao fato de se conseguir analisar não só o funcionamento dos elementos que caracterizam a coesão verbal, mas sua influência na elaboração da textualidade e na determinação da coerência temática (mesmo que parcialmente, já que, outros mecanismos também se encarregam dessa função). O importante é que o ensino da língua comece a pensar na questão verbal, não só a partir dos paradigmas que as gramáticas tradicionais nos trazem, mas também a partir de um ponto de vista textual/discursivo e, sobretudo, numa perspectiva de língua como interação, em que as práticas de linguagem são (re)configuradas em gêneros de textos, estes trazendo suas especificidades linguístico-discursivas e contextuais. 
A nossa contribuição para o letramento escolar se faz de uma maneira indireta, uma vez que não abordamos diretamente problemas de sala de aula, mas, sim, questões de descrição de fatores linguístico-discursivos que perpassam a funcionalidade de um gênero textual, que é, ao mesmo tempo, objeto de interação interpessoal e forte "candidato" a objeto de ensino da língua portuguesa. Não podemos esquecer que tomar o gênero como objeto de ensino da língua é também trabalhar a sua superfície linguística, pois só assim conseguiremos sair de um ensino gramatical conservador, abstrato, sem funcionalidade, para um ensino significativo e voltado para as práticas sociais.

\section{Referências}

BAKHTIN, Mikhail. Estética da criação verbal. Trad. Paulo Bezerra. 4. ed. São Paulo: Martins Fontes, 2003.

BAKHTIN, Mikhail/VOLOCHINOV, V. N. Marxismo e filosofia da linguagem. Trad. Michel lahud e Yara F. Vieira. 3. ed. São Paulo, HUCITEC, 1986.

BARROS, Eliana Merlin Deganutti. A apropriação do gênero crítica de cinema no processo de letramento. 2008. Dissertação (Mestrado em Estudos da Linguagem) - Universidade Estadual de Londrina, Londrina/PR.

BENVENISTE, Emile. O homem na linguagem. Trad. Isabel Maria Lucas Pascoal. 2a ed. Lisboa: Veja, 1992.

. Problemas de lingüistica geral I. Campinas: Pontes, 1995.

BRASIL. Ministério da Educação. Orientaçôes curriculares para o ensino médio Língua Portuguesa. Volume: Linguagens, códigos e suas tecnologias. Brasília: MEC/SEB, 2006.

Parâmetros curriculares nacionais: língua portuguesa (ensino de primeira a quarta séries). Brasília: MEC/SEF, 1997.

BRONCKART, Jean-Paul. O agir nos discursos: das concepções teóricas às concepções dos trabalhadores. Trad. Anna R. Machado e Maria de Lourdes M. Matêncio. Campinas: Mercado das Letras, 2008.

Atividade de linguagem, discurso e desenvolvimento humano. Trad. e org.

de Anna Rachel Machado e Maria de Lourdes M. Matencio. Campinas: Mercado de Letras, 2006.

Atividade de linguagem, textos e discursos: por um interacionismo sóciodiscursivo. Trad. Anna Rachel Machado, Péricles Cunha. São Paulo: EDUC, 2003. CORÔA, Maria Luiza M. Sales. O tempo nos verbos do português: uma introdução à sua interpretação semântica. São Paulo: Parábola, 2005. 
FIORIN, José Luiz. As astúcias da enunciação. São Paulo: Ática, 1999.

GERALDI, João Wanderley. Portos de passagem. São Paulo: Martins Fontes, 2003. GUIMARÃES, Ana Maria de Mattos; MACHADO, Anna Rachel; COUTINHO, Antónia (Org.). O interacionismo sociodiscursivo: questôes epistemológicas e metodológicas. Campinas: Mercado das Letras, 2007.

KLEIMAN, Ângela B. Modelos de letramento e as práticas de alfabetização na escola. In: (Org.). Os significados do letramento: uma nova perspectiva sobre a prática social da escrita. 9a reimpressão. Campinas: Mercado das Letras, 2006.

NASCIMENTO, Elvira Lopes. Gêneros textuais e ferramentas didáticas para a formação contínua de professores de língua portuguesa. In: SIMPÓSIO INTERNACIONAL DE ESTUDOS DE GÊNEROS TEXTUAIS, 4., 2007, Tubarão. Anais... Tubarão: UNISUL, 2007.

PRETO-BAY, Ana Maria Raposo. Acesso social, práticas educativas e mudanças teórico-pedagógicas ligadas ao gênero textual. In: SCHOLZE, Lia; RÖSING, Tânia M. K. (Org.). Teorias e práticas de letramento. Brasília/DF: INEP/UPF, 2007. REICHENBACH, Hans. Elements of symbolic logic. New York: The Free Press, $1947 / 1966$.

ROJO, Roxane. Letramento e diversidade textual. In: CARVALHO, Maria Angélica F. de; MENDONÇA, Rosa Helena (Org.). Práticas de leitura e escrita. Brasília: Ministério da Educação, 2006.

Modelização didática e planejamento: duas práticas esquecidas do professor? In: KLEIMAN, Ângela. A formação do professor: perspectivas da lingüística aplicada. Campinas: Mercado das Letras, 2001.

ROJO, Roxane \& MOITA-LOPES, Luiz Paulo. Linguagens, códigos e suas tecnologias. In: BRASIL. Ministério da Educação. Orientaçôes curriculares do ensino médio. Brasília: MEC/SEB, 2004.

RYAN, Maria Aparecida. Conjugação dos verbos em português. 13a ed. São Paulo: Ática, 1996.

SCHNEUWLY, Bernard \& DOLZ, Joaquim. Gêneros orais e escritos na escola. Trad. Roxane Rojo e Glaís Sales Cordeiro. São Paulo: Mercado das Letras, 2004.

TRAVAGLIA, Luiz Carlos. O aspecto verbal no português: a categoria e sua expressão. Uberlândia: editora da UFU, 1981.

Recebido em julho 2008. Aprovado em setembro de 2008 